Dubnitskyi V.I., Ivanova T.V., Naumenko N.Yu.

\title{
MODELING OF LOGISTIC PROCESSES OF PRODUCTION ECONOMIC SYSTEMS: THEORETICAL ASPECTS OF FORMATION AND FUNCTIONING
}

\author{
Ukrainian State University of Chemical Technology, Dnipro, Ukraine
}

\begin{abstract}
This article is considering construction of models, describing functioning of flexible production economic systems on industrial company level, based on modeling logistics processes. The model type is inherently a class of queuing system model with limited resources and switching industrial settings. The theoretical aspects of the logistics management of pulling and pushing production and logistics systems are considered. It justifies the need to formulate logistics tasks in terms of shifting the focus, from creating a stock of finished products, to creating production capacities, that is, moving to organizational production, such as flexible production and logistics systems (FPLS), which are able to quickly respond to dynamic market changes. The influence of modern conditions of functioning of an industrial enterprise on the market of manufacturers from rapidly changing position in the market of suppliers is shown. It is argued that the previously prevailing principles of maximizing production capacity and the use of available resources, in the face of fierce competition in the markets, should give way to a local approach to improve compliance with supplies, reducing stocks to the technologically necessary level. Substantiated methodical management concepts flexible production logistics systems. Has been shown, that new way in logistic lies in change priority in economic activities industrial companies. It is substantiated that the goal «consumer creation» fundamentally changes the methodical approach to planning and managing all production and business facilities in terms of introducing target priorities. Used schemes: logistic flows PES graphic interpretations of conception logistic production economic systems in the application economic-mathematical modeling (especially for terms systems massive services).
\end{abstract}

Keywords: Flexible production economic system, modeling of logistic processes of industrial production, logistic flows of PES, industrial logistics, marketing.

DOI: $10.32434 / 2415-3974-2018-8-2-11-20$

\section{Problem statement}

Becoming of Ukraine as an industrial country with market economy compel business weighed against its needs and costs, save public resources. This places high demands to company management, making them flexible and adaptable to external factors, ensuring maximum efficiency. Regular changing list of manufactured goods creates need to effective company management system, development new economic-mathematical models and approaches to its implementation.

Modern companies become more and more complicated systems. To provide controllability systems like this, we need new methods and models, that relevant complexity internal and external environment of company. New standard became appearance of controlling and logistic. Controlling includes company goal setting, collecting and processing information to take management decisions, implementation functions of controlling deviating actual indicators of performing from planed, also preparing suggestions take management decisions. The main ultimate goal of any enterprise is to make a profit, so they often say that controlling is a system for managing the profit of an enterprise. Logistics and controlling are closely interrelated, as they solve one and the same task - ensuring the profit of the enterprise.

In a competitive environment, work efficiency is directly dependent on how quickly it reacts to constant measurements in two different areas: in the field of security and sales. In this conditions company

(C) Dubnitskyi V.I., Ivanova T.V., Naumenko N.Yu., 2018 
success depend on rate of reaction constant changing in external infrastructure. In this regard, the company must have some mechanisms and management models that allow it to adapt to changing external conditions. This means that the company must be in constant relationship with suppliers of production resources and consumers of finished products. And it is the consumer who should determine the direction of his development. Thus, the solution to the problem of adapting an enterprise to changes in the external environment is closely related to solving the main task of modern enterprises - to create a consumer.

This goal radically changes the approach of modern enterprises to the problems of planning and management. Modern conditions for the functioning of an industrial enterprise in conditions of uncertainty and instability of the external environment require new, highly efficient ways and methods of managing its business activities. Traditional concepts of enterprise management include "never stop the main equipment and support its high utilization rate by all means", "make products as large as possible", "have the largest possible supply of material resources", "just in case" in market conditions are not able to maintain the efficiency of the enterprise at a high level, ensuring its organizational and economic sustainability. [1] At the same time, organizational and economic sustainability refers to the ability of an enterprise to maintain financial stability with a constant change in market conditions through the improvement and targeted development of its production, technological and organizational structure using logistic-oriented management methods. [2]

From all of the above, the transition from the traditional concept of production management to a new, most progressive, logistics concept of production management, which includes: the rejection of excess stocks; the rejection of the manufacture of a series of parts for which there is no order of customers; elimination of equipment downtime; the elimination of inefficient internal shipments; the transformation of suppliers from the opposing side into partners. [1]

Production under market conditions can survive if it is able to quickly change the range, quality and quantity of products. This problem large enterprises solves, most of which are in the Ukrainian economy, by creating a large stock of finished products in warehouses, since changing the range of products for large enterprises is a difficult task - it takes a lot of time and money to replace, install and overlay new equipment and equipment. equipment.

Logistics proposes to shift the focus from the creation of stocks of finished products to the creation of reserves of production capacity, that is, to move towards the creation and organization of production according to the type of flexible production and logistics systems (FPLS) that are able to respond quickly to changing market conditions. Reducing the cost of production is achieved as a result of the logistic organization of the production process, linking and synchronization of all material flows. A serious disadvantage of modern approaches to the organization of production is the fact that all technological systems are considered as ideal systems, i.e. deterministic. Observations on real objects, which we attribute to complex systems, show that they function under the conditions of a large number of random factors; therefore, the prediction of its behavior can make sense only within the framework of probabilistic categories.

Recently, an increasing attention of economists has taken an important scientific and practical direction in logistics and related management approaches, which make it possible to more effectively analyze and manage economic systems.

In the work of E. V. Krikavsky, logistics is interpreted as a kind of activity based on the deep integration of demand, production, circulation, transport, and information. This author notes that very often under the logistics understand the scientific direction, the purpose of which is to develop methods and organizational forms of management of streaming processes in order to meet the demand for products (goods, services, information, energy, etc.) and bring them to the consumer in due time with minimal cost. [3]

In the work of N.V. Rumyantsev it is indicated that the novelty of the logistic approach consists in changing the priorities of economic activity. In this case, the logistic approach orients the researcher to a greater degree not on the product, but on the process that takes the form of a stream (material, informational, etc.). Management of streaming processes, their transformation and integration are a new form of management, surpassing the traditional ones both in terms of creative potential and in the degree of efficiency of the final results. [6]

Modern conditions for the functioning of an industrial enterprise in the market of producers place it in complete dependence on the position in the market of suppliers and consumers. In the face of increasing competition, the success of any enterprise depends on the speed of response to constant changes in the external economic environment. Therefore, an enterprise should have effective management mechanisms that allow it to carry out a flexible response to changes in market conditions and competition in foreign and domestic markets of manufacturing enterprises. The implementation of this principle gives priority to the consumer in determining and shaping the areas of work of any enterprise. In this regard, the need is emerging to form organizational and economic conditions at enterprises that allow them to function normally in a developing market economy. Organizational and 
economic conditions, including a set of methods and algorithms for managing an enterprise under market conditions, should ensure the effective achievement of operating objectives, the generalization of which for all enterprises and production systems can be expressed with the thesis: "create a consumer".

Achievement of the goal in such a statement is related to the satisfaction of the entire range of needs of the consumer market by the profile of the products or types of services. The formation of a circle of stable consumers is the basis for the enterprise gaining a stable position in the producer market and involves identifying the interdependencies of the enterprise with all the infrastructure entities and developing the economic and mathematical apparatus for managing them.

\section{of work}

Analysis of research and publications on the topic

The problems of building models that describe the functioning of flexible production and logistics systems are dealt with by many prominent economists. Among the works devoted to this scientific direction one should single out the research of scientific schools of professors E. Krikavsky and Yu.G. Lysenko $[5,6,7,8,9]$, as well as the work of foreign scientists, among them E. Mate, D. Tixier [10], P. Bleick [11], D. Bowersox, D. Kloss [12], V.J. Stevenson [13], in the framework of the national school of logistics scientists should highlight the research A.M. Sumec [14], N.I. Chukhrai [15], O.S. Shkodina [16]. problem

The purpose and formulation of the research

The purpose of the study is to formulate the theoretical and methodological provisions of the concept of managing flexible production and logistics systems in the context of industrial enterprises. The objectives of the work should be considered: consideration of the process of functioning of the enterprise in a closed production and economic system (PES) in the application of industrial logistics tools; justification of the scheme of logistic flows of PES; to form an interpretation of the logistic production and economic system in basic terms of queuing systems.

\section{Presentation of the main research material}

The goal of «creating a consumer» radically changes the approach to planning and managing all production and economic facilities in terms of identifying target priorities. The previously dominant principles of maximizing capacity utilization and the use of available resources in modern conditions should give way to approaches to increasing the level of compliance with delivery terms, reducing stocks to the technologically necessary level, minimizing the production cycle by identifying internal productivity reserves and improving the rhythm of production processes. The solution of the task requires an integrated approach to the study of the complex of production and financial problems of all components of the procurement, production and sales processes. [6, p. 32]

By virtue of the complexity of the problem put forward, it is advisable to consider the enterprise as an industrial-logistic system, i.e. as a single organizational and economic system consisting of an industrial enterprise, suppliers of raw materials, materials and components, consumers of finished products, as well as including a system of transport and warehousing, shifting the emphasis of research on the relationship of suppliers with enterprises and enterprises with suppliers. In this regard, it is advisable to consider the enterprise as a production and economic system using the principles of logistics, the main idea of which is a comprehensive integrated approach to the movement of raw materials and finished products and is aimed at creating and monitoring the activities of a unified management system for production, economic and financial activities. - economic system. Moreover, this work should be carried out on the basis of economic and mathematical modeling. Proceeding from this, the functioning of an enterprise must be carried out within the framework of a closed production and economic system (PES) consisting of (see Fig. 1): directly the enterprise; warehouses for raw materials, equipment, semi-finished products, materials; finished goods warehouses that form an offer on the market of goods and services; consumer; block comparison, analyzing the relationship between supply and demand and forming, ultimately, the strategy of enterprise behavior. [6, p. 33]

With such a structure, the efficiency (performance) of the entire system as a whole increases.

The company in the process of its production and economic activity constantly enters into direct

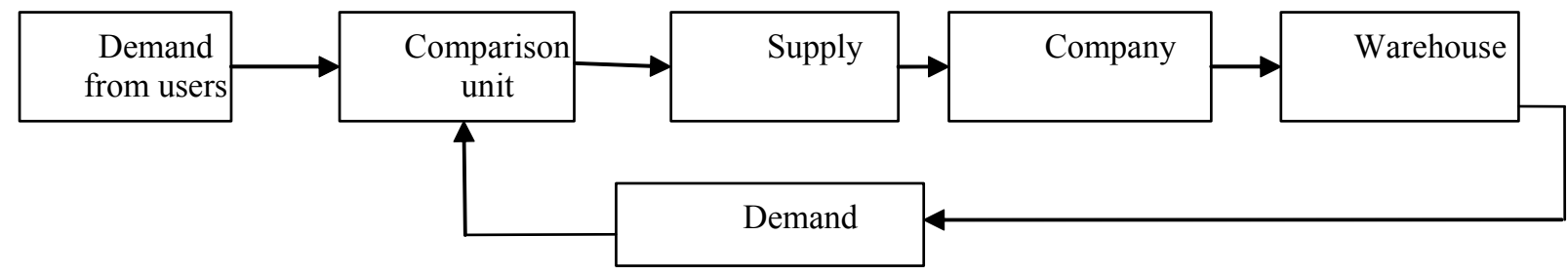

Fig. 1 Conceptual diagram of the operation of PES [6, p.33] 
and indirect relationships with suppliers, customers and competitors. The latter, proceeding from the goal of any enterprise - to create their own consumer, are trying to strengthen themselves in the market, thereby weakening the position of other enterprises.

Consumer creation for an enterprise is related to the degree of satisfaction of consumer demand in the goods of each type of nomenclature in terms of volumes and quality of the products supplied, time and place of delivery over a long period. If such a state is achieved by an enterprise, then we can assume that its activity is sustainable. When considering the approach to the assessment of the enterprise, it is necessary to keep in mind its organizational and economic stability, i.e. the ability of an enterprise to maintain financial stability with a constant change in market conditions through the improvement and purposeful development of its industrial, technological and organizational structure using logistic-oriented management methods. The formalization of the concept of «organizational and economic sustainability» and the management of this process is the main task of any enterprise (or PES) associated with the study of the integration of planning, analysis and control processes across all functional subsystems.

In the enlarged review of the activities of any PES, there are two outlines of management processes:

- revenue management in such a way that they remain at a certain level, exceeding a certain minimum, which guarantees the company financial stability;

- management of the structure of the production program of products from the point of view of its constant correspondence to the structure of consumer demand (nomenclature, quality and quantity of manufactured products).

In addition, there are two main contours of
PES disturbances. These are environmental fluctuations and technological innovation cycles. Environmental fluctuations include all kinds of changes occurring in it: changes in consumer demand; changes in the economic and political situation; changes in the structure of the supplier market; changes in the market of competitors; and etc.

The above disturbances take the company out of stable operation. The cycles of technical and organizational innovations (or the development of scientific and technological progress) are quite a strong disturbing factor, since they are both the cause of changes in consumer demand and prices for products, and the reason for the need to change the organizational and functional structures of various production and business units. Thus, the creation of a system that controls the interaction of these two circuits, will ensure the stability of the PES.

When considering each of the components of the PES structure, it becomes possible to define the goals and objectives of its subsystems, and, as a rule, when a single system is formed, they do not coincide with the purpose of the functioning of the entire system, i.e. there is a lack of coordination of local interests. The need to connect these divergent interests often leads to an increase in total costs in the process of converting raw materials to the type of finished products. Therefore, consideration of an enterprise as a PES based on the use of the principles of logistics, the main idea of which is a comprehensive integrated approach to the movement of raw materials and finished products, and aims to create and control the activities of a unified management system for production, economic and financial activities of PES, must be carried out on the basis of economicmathematical modeling.

When considering each of the components of a PES, their goals and objectives are defined, which,

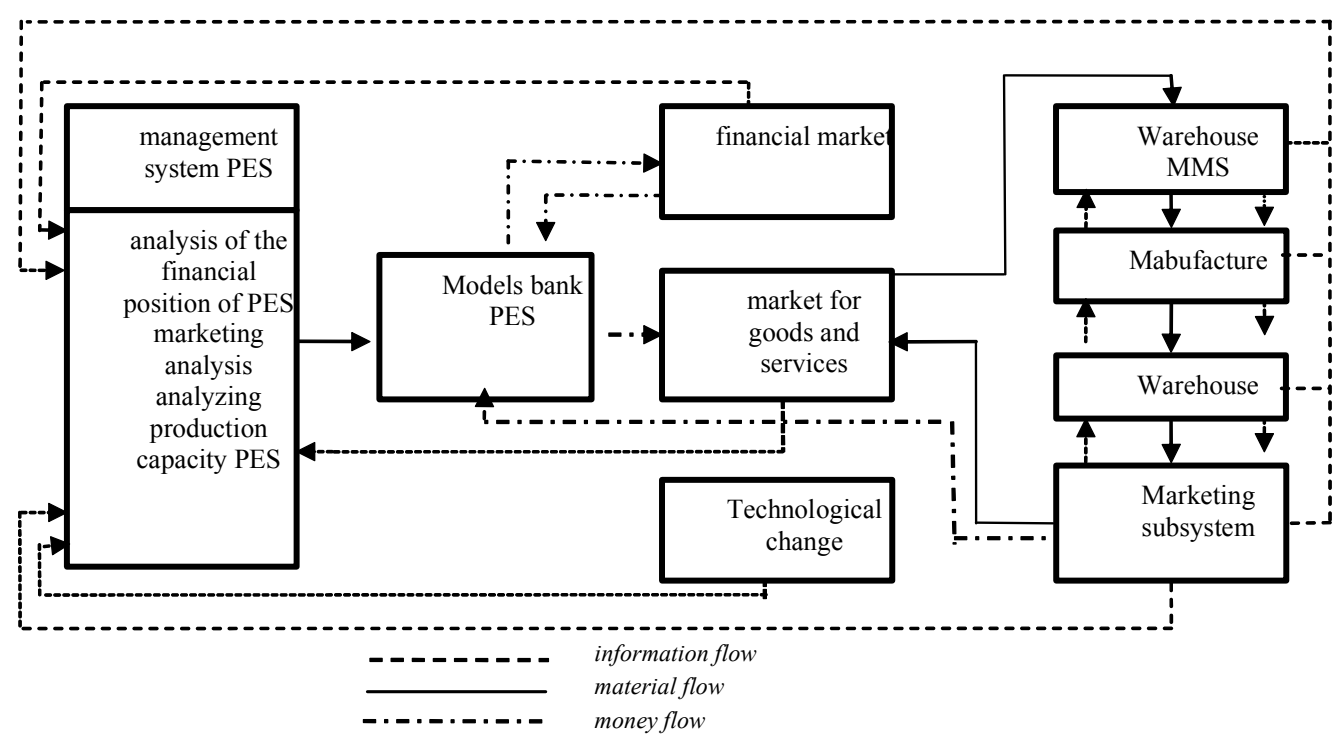

Fig. 2 Model of logistic flows PES 
when merged into a single system, usually do not coincide with the purpose of the functioning of the entire system, i.e. there is the principle of the emergence of the system - the whole has such qualities that are not inherent in any of its parts. Attempts to connect these mismatching interests often lead to an increase in total costs in the process of movement of raw materials to the finished product. Therefore, consideration of the enterprise as a PES based on the use of the principles of logistics, the main idea of which is a comprehensive integrated approach to the movement of raw materials and finished products, and aims to create and control the activities of a unified management system of production and economic and financial activities of PES, economic and mathematical modeling. In this regard, the operation of the enterprise must be carried out in a closed PES consisting of the enterprise itself, warehouses for raw materials, equipment, semifinished products, materials, finished product warehouses, forming an offer on the market of goods and services, a consumer, a control unit analyzing the relationship between demand and proposal and forming, ultimately, the strategy of the enterprise (see. Fig. 2). With such a structure, the efficiency (effectiveness) of the entire system as a whole increases.

The logistic approach identifies production processes with an interconnected aggregate of information and resource flows organized in space and time. Generally speaking, with the logistic approach, there is an alternation of information and material flows at each point of the value conversion chain. Flows of material resources and information circulate within the enterprise between its main functions: purchasing, production, sales, reproduction, marketing and personnel - the function of providing and consuming a specific resource - labor (Fig. 3), [6, p. 37].

At the present stage of development of the Ukrainian economy, particular attention should be paid to marketing as the main function that determines the attractive nature of production. Planning of any production activity must begin with an awareness of the needs of the market environment and an assessment of the urgency of their satisfaction. Marketing allows us to evaluate the complex market requirements imposed by consumers on the product and its properties, to identify the main directions of improving its quality and promotion mechanisms, including the after-sales service complex. Marketing ideology orients the manufacturer to the fullest possible satisfaction of consumer requirements and identifies areas of the most efficient use of production potential, whose criteria are indicators of the dynamics of gross sales.

Integrated marketing function of the enterprise involves the use of active and passive marketing tools. Passive marketing tools are represented by a set of analytical and diagnostic activities, the purpose of which is to identify consumer preferences, assess the depth and width of the occupied market segment, assess the dynamics of the influence of competitors on this market segment, identify ways to improve the proposed product and its properties. Passive marketing tools provide most of the estimates and projections, they are more distributed in time than active measures, and have a less deterministic result. At this stage, the larger share is controlled by the incoming information flow and its processing, carried

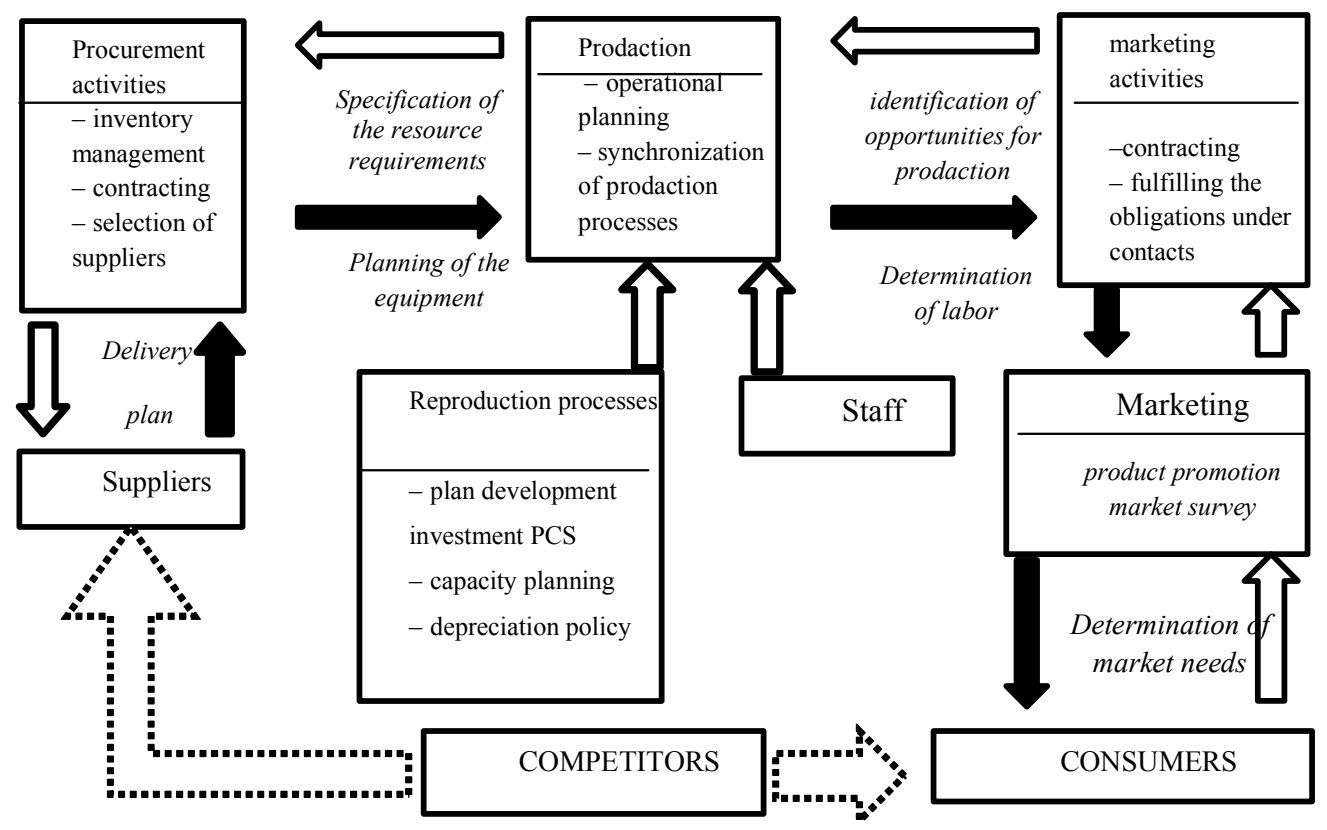

Fig. 3 The concept of logistics management of production and economic systems (authoring) 
out using the methods of mathematical statistics, econometrics and the forecasting apparatus. Distribution in time and the prevailing content make the cost of operating passive marketing tools, if not less significant, then at least less targeted. In addition, their effectiveness cannot be directly assessed, but only in a complex with the effectiveness of other logistic operations when a material flow occurs that satisfies the market demand.

Active marketing tools are a set of measures for after-sales service of the product and its promotion. The use of active tools due to the emergence of the material flow and serves the purpose of increasing the value of the goods in the postproduction period. The use of this toolbox completes the product production cycle.

The use of a marketing complex in an enterprise reveals in a market environment a specific source of consumption of a product and its properties - a particular consumer. Consumer awareness of the need for the product initiates the flow of information from him as a customer to the company, which, in the case of a contract, acts as a performer of the order. In turn, the sales function initiates the flow of information in the direction of the production function in order to identify production capabilities to meet customer needs.

In this case, a graph of the information flow may create loops related to planning, internal coordination of production conditions, identification of internal production reserves and coordination of local plans of subsystem

According to N.V. Rumyantsev, as a result of the implementation of a set of measures to identify production capacities, a plan for the production of products is constructed and local plans for loading subsystems are adjusted. The production function is the main source and consumer of flexibility in the economic system. On the one hand, the transition to flows and processes provides a different understanding of production processes, makes it possible to identify and use resources, and on the other hand, it is production processes that most need mechanisms for ensuring flexible and uninterrupted operation. [6, p.39]

The existence and functioning of the production function in the economic system causes a change in the qualitative content of the flows. It is the production functions that transform the entire set of flows of resource values into a new value, which is identified with the product being produced. Therefore, the allocation of the production function and effective management of it should be aimed at increasing the intensity of resource conversion into the final product by synchronizing subprocesses based on flexible planning of operations, dynamically determining the need for resources at each time point taking into account the lags due to their order and transportation, rhythm loading equipment while reducing the amount of unplanned downtime, disruptions and accidents in production.

The material flow, which has taken the form of a product, is sent to service by the sales function and then by the marketing function, thus completing the large contour of the material and information turnover of the economic system.

In view of the above, a new approach to their study is proposed from the position of the queuing theory, which is precisely engaged in analyzing various kinds of flows (application flows - customers, orders, resources, etc.). We describe the main approach, terminology, and some features used later in the simulation of an arbitrary PES as a queuing system (QT). First, we describe the main elements of a queuing system in terms of real PES. For this, as is known, it is necessary to describe the three main elements of the QT: input flow, service devices and service discipline.

Let us give an interpretation of the logistic production and economic system in terms of queuing systems, see $[1,4,10,12]$.

1. Input stream. The input flow in logistics systems is most often identified with the concept of material flow. The material flow in logistics is understood as material resources in motion, incomplete products and finished products, to which interrelated logistic operations and (or) functions related to physical movement are applied, starting with loading and unloading materials. from the source of raw materials to the consumption of finished products. [15]

The form of existence of the material flow, its content is significantly dependent on the stage of its advancement through the logistic system. For example, in relation to an enterprise, the material flow is represented by:

a) in the form of a stream of raw components and other auxiliary materials, in the case of procurement logistics, i.e. about providing the enterprise with material resources;

b) in the form of a stream of semi-finished or unfinished products - if we are talking about the production stage or production logistics;

c) in the form of finished products and spare parts - if we are talking about distribution logistics or, in other words, we are talking about the stage of distribution and marketing.

If the product is not in motion, it goes into stock, that is, a stock is a stopped material flow, or a stock is a material flow considered at a certain point in time. [6, p.41]

Each material flow corresponds to informational and financial flows, but this correspondence is not isomorphic, that is. and one-to-one.

Based on the positions of logistics, the material flow is characterized by certain parameters and can 
be classified according to several criteria.

In relation to the logistics system (LS), internal and external flows are distinguished. For industrial logistics, external material flows are flows that flow out of production, in the external environment. They can often be clearly unrelated to production and can be considered interference. However, they are often represented as input material flow entering a given logistic system. Internal material flows are flows that flow within the logistics system.

In relation to the link of the logistics system, material flows are subdivided into input and output flows. Through these types of material flows, communication is carried out between sections of the logistics system. In addition, through output material flows, the logistic system is connected with the external environment, influences it, and through them the process of adaptation of this form of the logistic system to external conditions is carried out.

According to the nomenclature, all streams are divided into single-product and multi-product. Single-product streams are streams containing one type of product or product.

According range flows can be divided into single-assortment and multi-assortment. The range is the composition and ratio of a certain type of product.

In the process of transportation, material flows can be classified according to the characteristics of the cargo, which includes the following characteristics: weight of the cargo, type of transportation, overall and physico-chemical properties, methods of steaming, etc.

Depending on the subject of study, material flows are divided into product, operational, precinct and systemic.

- Grocery material flows are those flows, the object of study of which is the movement of specific types of raw materials, products and means of labor.

- Operational material flows are the flows of material resources in relation to individual operations. For example, material flow on the operation of loading, unloading, etc. The parameter of the operational flow corresponds to the volume of work performed on individual operations for a certain period of time. These flows are the base, the basis for the calculation of local material flows.

- Precinct material flows - material flows operating in one section of the logistic system. The parameters of the local material flow are determined by summing the parameters of the individual flows.

- System flows are flows that flow through the entire logistics system. The parameters of the system flows are determined by summing the parameters of all the local material flows that flow or function in the logistic system. [6, p.43]

According to the rhythm of income, material flows are divided into discrete, continuous flows and blitz flows. Most material flows are discrete. Moreover, often continuous streams are modeled as discrete streams, with a specific quantization time. Continuous flows include, for example, flows of raw materials and materials in continuous closed-loop production processes, streams of water, oil products passing through pipelines, etc.

Discrete streams form products, objects entering the logistic system at specified intervals (deterministic or stochastic), namely: the organization of meeting the needs in the form of warehouse and transit supplies, the supply of material resources to workplaces in small-scale production and etc.

Blitz - flow is a one-time supply, shipment, supply of rarely used items and means of labor to work places.

According to the degree of regularity of income flows are divided into two classes: deterministic and stochastic. Deterministic flow is a flow with full known characteristics. One of the most important characteristics of a material flow is its intensity. The intensity of flow will be understood as the number of units of products supplied to the input of the logistic system per unit of time. We denote it by $\lambda>0$. A random flow is a flow in which at least one of the parameters is random. In theory and practice of analysis of logistic systems use two ways to set random flows:

a) let $\xi(\mathrm{t})$ be the number (volume) of parts (raw materials) that entered the logistic system during time $t$ and let the probability $\mathrm{P}_{\mathrm{k}}(\mathrm{t})$ be given that during the time $\mathrm{t}$, the system will receive $\mathrm{k}$ requirements, i.e. $\mathrm{P}_{\mathrm{k}}(\mathrm{t})=\mathrm{P}\{\xi(\mathrm{t})=\mathrm{k}\}$.

b) let $t_{0}, t_{1}, t_{2} \ldots$ be the moments of arrival of a discrete material flow into the logistic system, with $\mathrm{t}_{0}=0<\mathrm{t}_{1},<\mathrm{t}_{2}<\ldots<\mathrm{t}_{\mathrm{k}}<\mathrm{t}_{\mathrm{k}+1} \ldots$ and let $\mathrm{z}_{1}=\mathrm{t}_{1}-\mathrm{t}_{0}, \mathrm{z}_{2}=\mathrm{t}_{2}-$ $t_{1}, \ldots, z_{k}=t_{k}-t_{k-1}, z_{k+1}=t_{k+1}-t_{k}$. Then, to define the flow, it is necessary to describe a sequence of random variables $\left\{z_{k}\right\}$. If all values of $z_{k}, k \geq 1$ are independent, equally distributed, then by Kendall's classification, it is called an arbitrary independent flow and is designated as GI (general independent). If random variables $z_{k}$ are arbitrary, then such a stream is called arbitrary and denoted by the letter $\mathrm{G}$. If $\mathrm{z}_{\mathrm{k}}, \mathrm{k}>1$ are independent and have an exponential distribution law, then such a stream is denoted by the letter $M$ and is called the Poisson input stream. [6, p.43]

Note that deterministic flows are a special case of random flows, and are denoted by the letter D.

Material flows can be classified according to the degree of variability. According to this principle, stationary and nonstationary flows, ordinary and nonordinary flows are distinguished.

A flow is called stationary if the probabilistic characteristics of the process $\xi(t)$ do not depend on the time of the beginning of time, i.e. if we denote by $\xi\left(t_{0}, t\right)$ the number of parts that arrived during time $t$ in the interval $\left(t_{0}, t_{0}+t\right)$ and $\xi\left(t_{1}, t\right)$ is the number 
of parts that arrived in the time interval $\left(t_{1}, t_{1}+t\right)$, then the distribution of random variables $\xi\left(\mathrm{t}_{0}, \mathrm{t}\right)$ and $\xi\left(t_{1}, t\right)$ coincide, provided that the time intervals $\left(\mathrm{t}_{0}, \mathrm{t}_{0}+\mathrm{t}\right)$ and $\left(\mathrm{t}_{1}, \mathrm{t}_{1}+\mathrm{t}\right)$ do not cross.

A material flow is called ordinary if, in any sufficiently small time interval, more than one part (or a batch of parts) in the accepted measurement cannot be received.

In practice, it is often assumed that there is no after-effect in the material flow. This means that the arrival of requirements in the interval $\left(\mathrm{t}_{0}, \mathrm{t}_{1}\right)$ does not affect their receipt in the interval $\left(t_{2}, t_{3}\right)$, where где $\mathrm{t}_{1}<\mathrm{t}_{2}$.

It was shown [17] that the material flow satisfying all three properties: ordinary, stationary, and the absence of aftereffect, is Poisson, that is,

$$
\mathrm{P}\{\xi(\mathrm{t})=\mathrm{k}\}=\frac{(\lambda \mathrm{t})^{(\mathrm{k})}}{\mathrm{k} !} \mathrm{e}^{-\lambda \mathrm{t}}
$$

where the parameter $\lambda>0$ determines the intensity of the material flow, i.e. $\lambda=\mathrm{M} \xi$, i.e. Physically, $\lambda$ is defined as the average number of parts arriving in a unit of time.

A simple queuing system is a un closed-circuit in which the input $\mathrm{X}$ is transformed through the mapping f to the output $\mathrm{Y}$, and, as already noted, the input and output are usually specified as distribution functions. In the ratio $f:\{X, R\} \rightarrow Y$, it is most often assumed that a certain measure $M(X)$ defined on the space of input parameters is mapped to measure $\mathrm{M}(\mathrm{Y})$ specified on the space of output parameters, $\mathrm{F}(\mathrm{m}(\mathrm{X}))=\mathrm{F}(\mathrm{M}(\mathrm{Y}))$. In the particular case, this measure is given by the distribution function.

Similarly, one can approach more complex systems queuing service. Take, for example, a queuing system that simulates the production-economic system described above. The set of input elements in the described system has the form

$$
X-\left\{\tau_{i}^{e}, v_{i}^{e}, \tau_{i}^{\mathrm{s}}, v_{i}^{\mathrm{s}}, \xi, v\right\}, i=0,1,2,3, \ldots .
$$

The first two sequences determine the input flow to the queuing system, where $\tau_{i}^{\mathrm{e}}$ is the time between the arrival of (i-1)-th and 1st requirements, i.e. at time points

$$
\tau_{0}^{\mathrm{e}} ; \tau_{0}^{\mathrm{e}}+\tau_{1}^{\mathrm{e}} ; \tau_{0}^{\mathrm{e}}+\tau_{1}^{\mathrm{e}}+\tau_{2}^{\mathrm{e}} ; \ldots
$$

Requirements come in batches of volume $v_{0}^{\mathrm{e}}$, $v_{1}^{\mathrm{e}}, v_{2}^{\mathrm{e}}, \ldots$ respectively.

The second two sequences $\left\{\tau_{i}^{\mathrm{s}}\right\}$ and $\left\{v_{\mathrm{i}}^{\mathrm{s}}\right\}$ are used to describe the process of servicing calls (orders): calls are serviced by batches, $v_{0}^{\mathrm{s}}, v_{1}^{\mathrm{s}}, v_{2}^{\mathrm{s}}$ (or batches of smaller volumes, if there were not enough calls in the system), while servicing the $\mathrm{k}-$ th batch of applications takes time $\tau_{\mathrm{k}}^{\mathrm{s}}$. Random variable o determine the number of sources of applications. If $\xi$ is, of course, then we have a closed-type queuing system; if $\xi=\infty$, then the system is considered an open queuing system; if $\xi$ is a random variable, then the flow of requirements into the system depends on the state of the system, $L$ is the length of the switching interval of service devices from the reserve to the working state.

Let us describe the possible restrictions of $\mathrm{R}$ in the model under consideration.

1. The discipline of service - it is assumed that the service requirements in the order received. Possible work in priority mode.

2. Restrictions on the number of waiting places only exist for a warehouse of finished products.

3. Waiting time - in general, there is a limitation on the time, waiting and stay of the order in the system, i.e. time from the moment the order is received at the enterprise until it is received by the consumer;

4. There are various ways of self-regulation and adaptation that

a) the number of service devices can vary from 0 to $n+n_{1}$, where $n_{1}$ is the number of devices in reserve;

b) interruption of receipt of requirements in the case when the supply far exceeds demand, and the comparison unit blocks the flow of new requirements;

c) it is assumed that there is some quality functional that takes into account all limitations, but in terms of value.

The output of system $\mathrm{Y}$ is

$\mathrm{Y}=\left\{\mathrm{W}, \mathrm{Q}_{1}, \mathrm{Q}_{2}, \mathrm{Q}_{3}, \mathrm{I}, \mathrm{K}, \mathrm{C}\right\}$,

where $\mathrm{W}$ is the waiting time for the start of order service in stationary mode; $Q_{1}$ - is the queue length in the stationary mode; $\mathrm{Q}_{2}-$ the size of the stock of the warehouse of material resources; $\mathrm{Q}_{3}-$ stock size of the warehouse of finished products; I - length of the heating interval of the device; $\mathrm{K}$ - is the length of the busy period of the system; $\mathrm{C}-$ is the optimal value of the cost functional.

For the described queuing system model, it is necessary to define the rule $\mathrm{f}$, which allows to calculate the output parameters $\mathrm{Y}$ as functions of the system input parameters.

It should be noted that the solution of this problem is fraught with certain difficulties of a twofold nature:

1) obtaining analytical expressions for the laws of the distribution of output parameters $\mathrm{Y}$;

2) finding the stability conditions for these 
parameters.

To solve these problems, the methods of the theory of mass service, the theory of Markov chains, the theory of reserves, optimal control, and the theory of optimization are used. [6, p. 51]

As mentioned earlier, one of the important tasks of industrial logistics is the task of rational use of storage facilities, which, ultimately, should lead to the minimization of stocks. This problem is closely related to the issues of determining the optimal size of the lot and the time between deliveries. The problems of the theory of stocks were considered both in deterministic and random premises. The greatest interest in this direction are the works of J. Bukan and E. Koenigsberg, N. Prabhu, Yu.I. Ryzhikova, J. Hadley and T. Whitin, G.B. Rubalsky and many other authors.

However, from our point of view, the most natural method of studying logistic systems is the theory of queuing, which investigates flow processes and their transformation both in the deterministic, and in the stochastic case. It should be noted that for the first time the issues of application of the theory of mass service to solve problems of organization and strategic production planning were considered in the works of the Dutch mathematician A. Erlang and the Russian scientist B.V. Gordienko Erlang for the first time applied the theory of mass service to solving the problem of determining the optimal number of telephone lines in a telephone company. B.V. Gnedenko solved the problem of determining the optimal number of repair teams needed to organize the repair of industrial equipment failing at random times. In the future, a large number of papers devoted to the application of queuing theory appeared, for example, N.M. Vorobyova, F.N. Gabeleva, Yu.I. Neymarka, J. Gergey, A.M. Gortseva, E.S. Klimov and others, to build automated production management systems. The queuing systems considered in these papers are now called classical systems.

\section{Conclusions}

Finally, we note that any economic system is a dynamic system and, therefore, using a dynamic approach for its analysis allows one to achieve greater results than studying it in statics. When studying the behavior of dynamic systems, the researcher is interested in the system itself, the goals of its functioning and the environment of functioning. The external environment sets the "corridor" in which the system functions. One of the most important characteristics of the economic system is its stability. Stability characterizes the ability of the system to maintain its characteristics regardless of external disturbances. Stability does not mean inertia, "stiffness" of the system; on the contrary, a stable system is able to respond flexibly to disturbances, to adapt to changes, that is, to work effectively. In essence, the concept of stability determines the behavior of the system, its response to external disturbances that come from the external environment.

For deterministic economic systems, two types are considered: the system stability according to Mesarovich and the stability according to Lyapunov. For stochastic queuing systems, the concept of stability is often associated with the concept of stationarity of a system, i .e. the independence of the probability characteristics of the system from time to time. For such systems, the main task is to find the stationary characteristics of the system and the conditions under which the system operates stably. The question of finding sustainable solutions is of particular interest in the application to economic systems.

\section{REFERECES}

1. Nikolaychuk V. E., Kuznetsov V. G. (1999) Theory and practice of management of material flows (logistic concept: monography) - Donetsk: Don GU. «Kitis». 413 p.[in Ukrainian]

2. Omelchenko I. N., Kolobov A. A., Ermakov A.Yu., Edited by Korobov A. A. (1997). Industrial Logistics. Logisticsoriented management of organizational and economic sustainability of industrial enterprises in a market environment. M: Publishing House of Moscow State technical University. Bauman. 204 p. [in Russian]

3. Krikavsky E. V. (2005) Logistic management: Pidruchnik. - Lviv: view of National University "Lviv PoliPEShnika”. 684 s. [in Ukrainian]

4. Nikolaychuk V. E. (2001) Logistics. - SPb: Peter. 160 p. [in Russian]

5. Krikavsky E. V. (2004) Logistics. Establish a theory: Lviv: view of the National University Lviv PolyPEShnic 416 p. [in Ukrainian]

6. Rumyantsev N. V. (2004) «Modeling of flexible production and logistic systems». - Donetsk: Don GU. 235 p. [in Ukrainian]

7. Lysenko Yu. G., Petrenko V.L., Rumyantsev N.V. (2000) The concept of logistics management of production and economic systems / / Sb. scientific Tr.- Donetsk: Don NU-UkrNTEK. from. 43-50. [in Ukrainian]

8. Lysenko Yu. G., Petrenko V. L., Rumyantsev N. V. The concept of logistics management proizvodsvenno-economic systems based on the theory of mass service // herald Don NU. - Ser. «Economics and Law.» - Donetsk: №2. 173-178. [in Ukrainian]

9. Veselovsky M., Bilyk I., Deinega O. et al .: Economics of Logistic Systems (2008): monograph. /: For Sciences. Ed. Krikavsky E.V., Kubiv S.I. -Lviv: view of National University "Lviv Politechnika". 596 p. [in Ukrainian]

10. Mate E., Tixier D. (2003) Logistics: trans. from French Ed. Kuprienko N.V.. - SPb: NEVA publishing house. - 128 p.

11. Vlaik R. (1999) Logistyka. - Warszawa: PWE. 244 s. [in Poland] 
12. Bauerson D. Kloss D. (2001) Logistics: an integrated supply chain: Per. from English - M .: ZAO Olimp-Business. 640 p.

13. Stevenson V.J. (1998) Production Management: Per. from English - M: ed. «Binomial». 928 p.

14. Sumets A. M. (2010) Is it possible to organize logistics clusters in Ukraine // Logistics: problems and solutions. № 6 18-27. [in Ukrainian]

15. Chukhrai M. I. (2003) Logistic concepts and real economics of Ukraine // Newsletter of Lviv PolyPEShnic National University: №484: Problems of economics and management. 193198. [in Ukrainian]

Received 20.10.2018

Reviewer: prof. Kolesnikov V.P.

\section{МОДЕЛЮВАННЯ ЛОГІСТИСТИЧНИХ ПРОЦЕСІВ ВИРОБНИЧО-ЕКОНОМІЧНИХ СИСТЕМ: ТЕОРЕТИЧНІ АСПЕКТИ ПОБУДОВИ І ФУНКЦІОНУВАННЯ}

\section{Дубницький В.І., Іванова Т.В., Науменко Н.Ю.}

В роботі розглядаються питання побудови моделі, що описують функціонування гнучких виробничо-економічних систем на рівні промислових підприємств, на основі моделювання логістичних процесів. Тип моделі відноситься за своєю сутністю до класу моделей систем масового обслуговування з обмеженим ресурсом і переналагодженням умов промислового налагодження. Обгрунтовано необхідність сформулювати завдання логістики в частині перенесення акценту, зі створення запасу готової продукиії, для запасу створення виробничих потужностей, тобто, переходу до організаційного виробництва, за типом гнучких виробничо-логістичних систем (ГВЛС), яка в змозі швидко реагувати на динамічні зміни кон юнктури ринку. Показано вплив сучасних умов функціонування промислового підприємства на ринку виробників , положень що швидко змінюються на ринку постачальників. Стверджується, що домінуючі раніше принципи максимізації виробничих потужностей $i$ використання доступних ресурсів, в умовах жорсткої конкуренції на ринках, повинні поступитися місцевим підходом щодо підвищення рівня дотримання поставок, зниженням запасів до технологічно необхідного рівня. Обтрунтовано методичні положення концепиії управління гнучкими виробничо-логістичними системами. Показано, що новизна логістичного підходу полягає в зміні пріоритету в господарської діяльності промислового підприємства. Обгрунтовано, що мета «створення споживача» кардинально змінює методичний підхід до планування та управління всіма виробничо-господарськими об'єктами з точки зору введення цільових пріоритетів. Надані в роботі схеми: логістичних потоків ВEC і графічна інтерпретація концепції логістичного виробничо-економічними системами при застосуванні економіко-математичного моделювання (в т.ч. в термінах систем масового обслуговування)

Ключові слова: Гнучка виробничо-економічна система, моделювання логістичних процесів промислового підприємства, логістичні потоки в рамках ВЕС.

\section{МОДЕЛИРОВАНИЕ ЛОГИСТИСТИЧЕСКИХ ПРОЦЕССОВ ПРОИЗВОДСТВЕННО- ЭКОНОМИЧЕСКИХ СИСТЕМ: ТЕОРЕТИЧЕСКИЕ АСПЕКТЫ ПОСТРОЕНИЯ И ФУНКЦИОНИРОВАНИЯ}

\section{Дубницкий В.И., Иванова Т.В., Науменко Н.Ю.}

В работе рассматриваются вопросы построения модели, описывающие функционирование гибких производственноэкономических систем на уровне промышленных предприятий на основе моделирования логистических процессов. Тип модели относится по своей сути к классу моделей систем массового обслуживания с ограниченным ресурсом и переналадками условий промышнной отладки. Обоснована необходимость сформулировать задачи логистики в части переноса акцента с создания запаса готовой продукции, для создания запаса производственных мощностей, то есть, перехода к организационному производству, по типу гибких производственно-логистических систем (ГВЛС), которые в состоянии быстро реагировать на динамические изменения рынка. Показано влияние современных условий функционирования промышленногоо предприятия на рынке производителей. Утверждается, что доминирующие ранее принципы максимизации производственных по-мощностей и использования доступных ресурсов, в условиях жесткой конкуренции на рынках, должны уступить местным подходом по повышению уровня соблюдения поставок, снижением запасов до технологически необходимого уровня. Обоснованы методические положения концепции управления гибкими производственно-логистическими системами. Показано, что новизна логистического подхода заключается в изменении приоритета в хозяйственной деятельности промышленного предприятия. Обосновано, что цель «создание потребителя» кардинально меняет методический подход к планированию и управлению всеми производственно-хозяйственными объектами с точки зрения введения иелевых приоритетов. Представленные в работе схемы: логистических потоков ВЭС и графическая интерпретация кониепиии логистического производственно-экономическими системами при применении экономико-математического моделирования (в.ч. в терминах систем массового обслуживания)

Ключевые слова: Гибкая производственноэкономическая система, моделирование логистических процессов промышленного предприятия, логистические потоки в рамках ВЭС. 